\title{
Cerebral spectroscopic and oxidative stress studies in patients with schizophrenia who have dangerously violently offended
} Ian H Treasaden $* 1,2$ and Basant K Puri ${ }^{1}$

Address: ${ }^{1}$ Imperial College, London, UK and ${ }^{2}$ West London Mental Health NHS Trust, UK

* Corresponding author

from International Society on Brain and Behaviour: 3rd International Congress on Brain and Behaviour

Thessaloniki, Greece. 28 November - 2 December 2007

Published: 17 April 2008

Annals of General Psychiatry 2008, 7(Suppl I):S88 doi:I0.II86/I744-859X-7-SI-S88

This abstract is available from: http://www.annals-general-psychiatry.com/content/7/SI/S88

(c) 2008 Treasaden and Puri; licensee BioMed Central Ltd.

Cerebral spectroscopy is a non-invasive technique that allows us to study the chemistry of the living brain, while exhaled breath analysis allows us to study oxidative stress. We shall present an overview of these techniques and review the findings of studies in which these techniques have been applied to patients with schizophrenia who have dangerously violently offended. The implications for the role of fatty acids in the aetiology and treatment of neuropsychiatric disorders generally will be discussed. 